한국농림기상학회지, 제16권 제1호(2014) (pISSN 1229-5671, eISSN 2288-1859)

Korean Journal of Agricultural and Forest Meteorology, Vol. 16, No. 1, (2014), pp. 39 50

DOI: 10.5532/KJAFM.2014.16.1.39

(C) Author(s) 2014. CC Attribution 3.0 License.

\author{
용문산 산악지역의 봄철 기온특성 \\ 천지민 ${ }^{1}$ - 김규랑 ${ }^{1 *}$ - 이선용 ${ }^{1} \cdot$ 강위수 $^{2}$ - 최종문 ${ }^{1}$ - 홍순성 ${ }^{3}$ - 박종선 ${ }^{2}$ - \\ 박은우 ${ }^{2} \cdot$ 김용삼 $\cdot$ 최영진 ${ }^{1} \cdot$ 정현숙 ${ }^{1}$ \\ 1국립기상연구소 응용기상연구과, ${ }^{2}$ 국가농림기상센터, \\ 3경기도 농업기술원, ${ }^{4}$ 양평군 농업기술센터
}

(2014년 1월 20일 접수; 2014년 3월 13일 수정; 2014년 3월 19일 수락)

\title{
Characteristics of Springtime Temperature Within Mt. Youngmun Valley
}

\author{
Ji Min Chun ${ }^{1}$, Kyu Rang Kim ${ }^{1 *}$, Seon-Yong Lee', Wee Soo Kang ${ }^{2}$, Jong Mun Choi ${ }^{1}$, \\ Young-Jean Choi ${ }^{1}$, Soon Sung Hong ${ }^{3}$, Yong Sam Kim ${ }^{4}$ and Hyun-Sook Jung ${ }^{1}$ \\ ${ }^{1}$ Meteorological Application Research Laboratory, National Institute of Meteorological Research, \\ ${ }^{2}$ National Center for Agro Meteorology, \\ ${ }^{3}$ Gyeonggi-do Agricultural Research and Extension Services, \\ ${ }^{4}$ YangPyeong Agricultural Development and Technology Center \\ (Received January 20, 2014; Revised March 13, 2014; Accepted March 19, 2014)
}

\begin{abstract}
This paper reviews the results of recent observations in the Yeonsuri valley of Mt. Youngmun during springtime (March to May) in 2012. Automated weather stations were installed at twelve sites in the valley to measure temperature and 2, 3 dimensional wind. We examined temporal and spatial characteristics of temperatures and wind data. The Yeonsuri valley springtime average temperature lapse rate between the top and bottom of the entire period is $-0.44^{\circ} \mathrm{C} / 100 \mathrm{~m}$. It can be changed by the synoptic weather conditions, the lapse rates is greatest in order of clear days $\left(-0.48^{\circ} \mathrm{C} / 100 \mathrm{~m}\right)$, rainy $\left(-0.41^{\circ} \mathrm{C} / 100 \mathrm{~m}\right)$ and cloudy days $\left(-0.40^{\circ} \mathrm{C} / 100 \mathrm{~m}\right)$. In the night, the temperature inversion layer (thermal belt) and the cold pool are formed within the valley. In addition, we measured temperature and wind distribution from the bottom to $3.5 \mathrm{~m}$, the cold layers existed up to $1.5 \mathrm{~m}$, which were affected by ground mixed layer. The results will provide useful guidance on agricultural practices as well as model simulations.
\end{abstract}

Key words: Mountain observation, Temperature laps rate, Valley wind

\section{I. 서 론}

기상기술의 발달과 농업 대처 능력이 향상됨에 따라 각종 기상재해로 인한 농가의 피해를 관리하고 감소시 킬 수 있게 되었다. 그러나 국지적으로 발생하는 기상 현상에 대해서는 정보가 제공되지 않는 문제가 있다.
최근 지구온난화로 인해 겨울의 길이가 짧아지고 최저 기온이 상승함에도 불구하고 동해는 자주 발생되고 있 다(Lee et al., 2010). 과수재배는 국지기후와 미기후 에 큰 영항을 받고 있으며, 동해 및 상해는 피해를 입게 되면 해당연도에 대해, 또는 영속적으로 생산력 을 잃게 만들므로 병충해와 더불어 생산량에 크게 영 
향을 끼치는 요인이다. 산지에 위치한 과수원에서는 냉기류가 평지로 흘러가는 통로가 되어 사방의 냉기류 가 장시간 정체되는 경우 동해 및 상해의 피해를 입 는다.

동해 및 상해의 원인이 되는 저온 현상은 지형학적 으로 피해가 자주 발생하는 지역이 있어 국지적인 저 온 발생을 예측하기 위해 과수원 주변의 공기 흐름을 관측하고 저온 발생을 모니터링 할 필요가 있다. 그러 나 산지에서의 기상관측은 설치 및 운영의 어려움으로 인해 매우 제한적으로 연구되고 있다. 이러한 어려움 에도 불구하고 $\operatorname{Song}(2000)$ 은 경기도 남양주군의 산간 곡지에서 관측을 수행하여 일기, 식생, 사면의 방향, 해발고도에 따른 기온차이를 비교하여 겨울철 산지의 기온 분포 변화 과정을 살펴보았다. Choi et al. (2010)은 강원도 양구군 산간분지에서 자동기상관측망 자료를 분석하여 여름철 시간 및 종관기상에 따른 기 온감률의 특성을 밝히고, 냉기호, 온기호의 형성에 관 해 연구하였다.

본 연구에서는 이러한 선행연구에서 나아가 산지에 서 발생하는 기상현상을 더욱 조밀하고 정밀하게 관측 하여 국지적인 산지의 기온분포 특징에 대해 알아보고 자 하였다. 용문산 산악지역을 대상으로 종방향 및 횡 방향으로 관측지점을 선정하고, 지점별로 4 개의 높이
에서 기온 및 바람을 측정하여 국지적 기상현상을 보 다 세밀히 측정하고자 하였다. 이 자료를 바탕으로 봄 철 용문산 산간지역의 기상 특성에 대해 알아보았다.

\section{II. 연구지역 및 방법}

경기도 양평군은 동, 북, 서로 높은 산들이 둘러 쌓 여있는 분지 형태를 이루고 있으며, 산악형 분지 기후 의 특징을 나타내어 같은 위도의 동해안 지방에 비해 연평균기온이 낮다. 그리고 주변에 위치한 북한강 상류 의 댐이나 팔당댐 등이 한강수의 유동을 막아 겨울에 쉽게 동결되는 강물로 인해 내륙은 야간 복사냉각의 영향을 받는다(Hong and Ryu, 1997). 2010-2011년 경기도 농업기술원의 동상해 피해자료에 따르면 양평은 중부내륙에 위치함에도 불구하고 피해가 크게 나타났다 (경기도 농업기술원 내부자료). 연구대상지역인 연수리 배 과수원은 양평군 용문산 $(1157 \mathrm{~m})$ 의 남쪽 백운봉 $(840 \mathrm{~m})$ 아래의 연수리 계곡에 위치하여 찬 공기흐름 및 정체에 의한 저온 피해의 발생이 잦은 곳이다.

본 연구에서는 경기도 연수리 일대에서 기온 및 바 람의 변화를 2012년 3월부터 5월까지 관측하였다. 연 수리 계곡 하류 지역 중 냉기 형성 과정과 계곡 중류 지역 온난대 형성 과정을 감시하기 위해 종방향

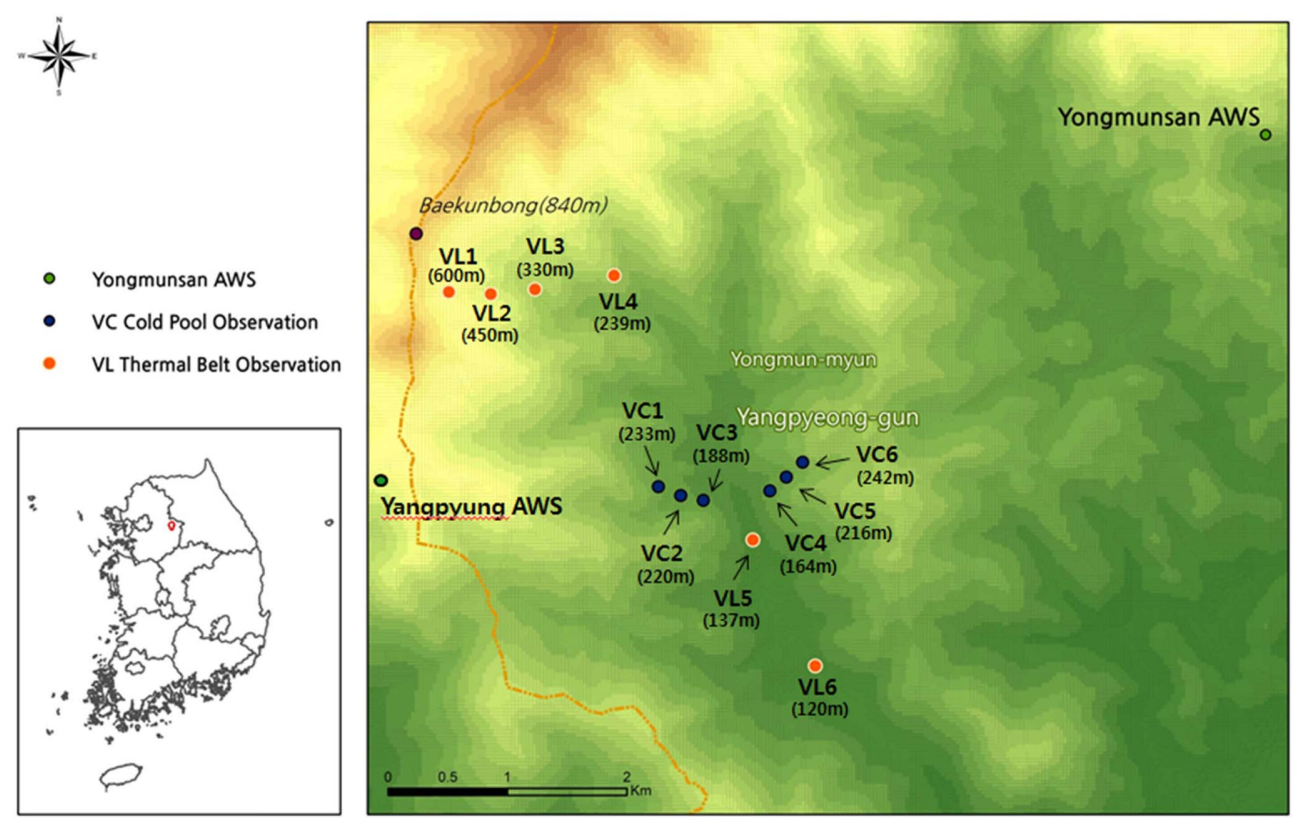

Fig. 1. Distribution of weather observational sites (AWS) for cold air pool (VC1 VC6) and thermal belt (VL1 VL6) in the Yeonsuri valley of Mt. Yongmun during March to May in 2012. 
Table 1. Details of observation of station

\begin{tabular}{|c|c|c|c|c|}
\hline $\begin{array}{l}\text { Station } \\
\text { name }\end{array}$ & $\begin{array}{l}\text { Latitude } \\
\text { (degree) }\end{array}$ & $\begin{array}{l}\text { Longitude } \\
\text { (degree) }\end{array}$ & $\begin{array}{l}\text { Height } \\
(\mathrm{m})\end{array}$ & Observed variables \\
\hline VL1 & 37.534006 & 127.533674 & 600 & 2D Wind, Temp \\
\hline VL2 & 37.533838 & 127.537649 & 450 & 2D Wind, Temp \\
\hline VL3 & 37.534170 & 127.541836 & 330 & Temp \\
\hline VL4 & 37.535176 & 127.549324 & 239 & 2D Wind, Temp \\
\hline VL5 & 37.515168 & 127.562321 & 137 & 2,3D Wind, Temp \\
\hline VL6 & 37.505636 & 127.568167 & 120 & 2D Wind, Temp \\
\hline $\mathrm{VC} 1$ & 37.518178 & 127.555161 & 233 & Temp \\
\hline $\mathrm{VC} 2$ & 37.517939 & 127.555551 & 220 & 2D Wind, Temp \\
\hline $\mathrm{VC} 3$ & 37.517563 & 127.557035 & 188 & Temp \\
\hline $\mathrm{VC} 4$ & 37.517790 & 127.564151 & 164 & Temp \\
\hline $\mathrm{VC} 5$ & 37.518949 & 127.565667 & 216 & 2D Wind, Temp \\
\hline VC6 & 37.519477 & 127.566292 & 242 & Temp \\
\hline Yangpyung AWS & 37.48883 & 127.494423 & 693 & Temp, Wind, Pressure, Relative humidity \\
\hline Mt. Youngmun AWS & 37.60002 & 127.583151 & 815 & Temp, Wind, Pressure, Relative humidity \\
\hline
\end{tabular}

(Valley aLong: VL1 6) 및 횡방향(Valley aCross: $\mathrm{VC1} 6$ )으로 각 6개씩 관측지점을 선정하였다(Fig. 1). 모든 지점에서 온도는 $0.5 \mathrm{~m}, 1 \mathrm{~m}, 1.5 \mathrm{~m}, 3.5 \mathrm{~m}$ 높이 에서 관측을 하였고, 공기의 흐름 및 방향을 알아보기 위해서 2,3 차원 초음파 풍속계를 $1 \mathrm{~m}, 3.5 \mathrm{~m}$ 에 설치 하였다(Table 1, Fig. 2). 풍속계는 온난대 형성을 관 측하기 위해 백운봉 정상아래 고도 $600 \mathrm{~m}$ 지점(VL1)과 백운봉 중턱(VL2), 골짜기 초입(VL4)에 설치하고, 냉 기호의 형성과 냉기 흐름을 관측하기 위해 연수리 계 곡 중심부의 동쪽 및 서쪽에 있는 두 야산의 중턱 (VC2,5)과 평지(VL5) 그리고 계곡의 하류(VL6)에 설치 하였다. 2차원 바람을 관측하기 위한 장비는 WINDSONIC1-L (Campbell Scientific, Inc., Logan, UT,

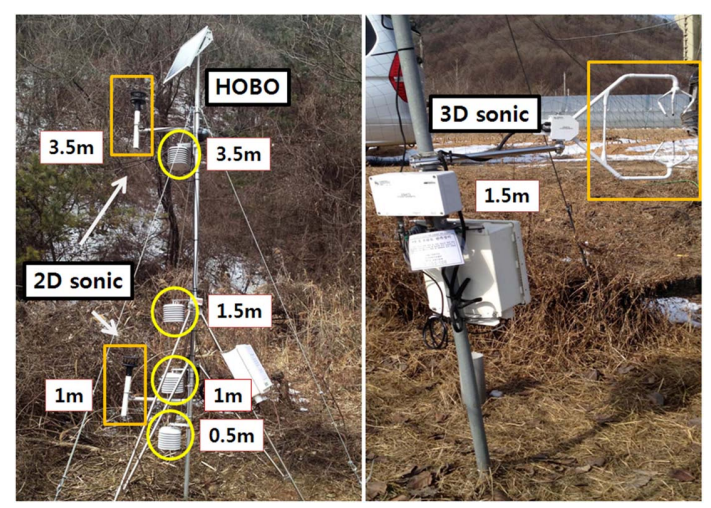

Fig. 2. Detailed pictures of weather observational equipments at the observational sites.
U.S.A.), 3차원 바람을 관측한 장비는 CSAT3 (Campbell Scientific, Inc.)을 사용하였으며 CR800 (Campbell Scientific, Inc.) 자료집록기를 이용하여 관측자료를 수 집 및 저장하였다. 그리고 기온은 $\mathrm{HOBO}$ Pro V2 (Onset Computer Corporation, Cape Cod, MA, U.S.A.) 를 사용하였다. 2차원 바람은 WINDSONIC1-L를 이 용하여 2 초마다 2 차원 바람 속도를 각 관측지점마다 $100,350 \mathrm{~cm}$ 높이에서 관측하고 5 분마다 평균을 계산 하여 저장하였다. 3차원 바람은 VL5 지점의 $150 \mathrm{~cm}$ 높이에서 $\mathrm{CSAT} 3$ 를 이용하여 초당 10 회 3 차원 바람 속도를 관측하고 10 분마다 평균을 계산하여 저장하였 다. 기온과 상대습도는 $\mathrm{HOBO}$ Pro V2를 이용하여 각 지점마다 $50,100,150,350 \mathrm{~cm}$ 높이에서 10 분마 다 관측하고 저장하였다. 관측자료 품질관리시스템은 기상청에서 이미 개발해 놓은 기상관측자료 실시간 품 질관리시스템(RQMOD, real-time quality control system for meteorological observation data; Heo et al., 2005) 중 $\mathrm{AWS}$ 관측자료 $\mathrm{QC}$ 모듈을 활용하여 농업현장 $\mathrm{AWS}$ 관측자료의 품질관리시스템으로 구현한 것이다. $\mathrm{RQMOD}$ 의 $\mathrm{AWS}$ 관측자료 $\mathrm{QC}$ 모듈은 물리한계검사, 기후범위검사, 단계검사, 지속성검사, 중앙값필터검사 등의 과정을 거쳐서 관측자료의 품질관리를 수행한다. 물리한계검사에 필요한 각 관측 요소별 문턱값 (threshold)들은 농업용 AWS의 관측자료들의 요소별 극값, 센서의 측정범위, 기상청 $\mathrm{RQMOD}$ 에서 이용하 는 물리한계값을 함께 고려하여 결정하였다. 기온의 
VL1

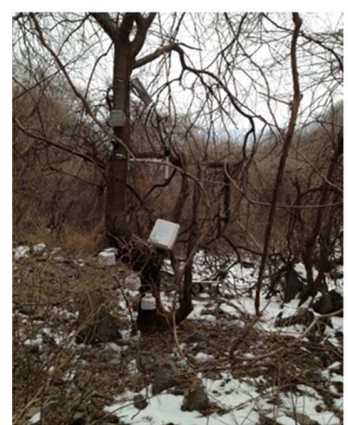

VL4

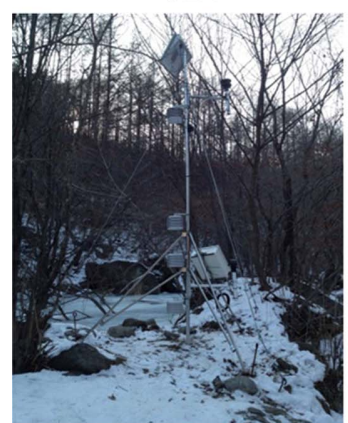

VL2

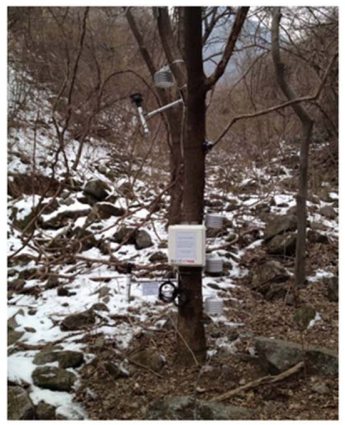

VL5

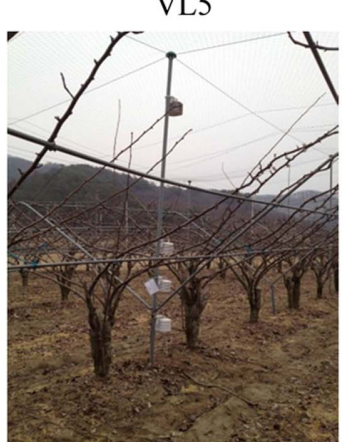

VL3
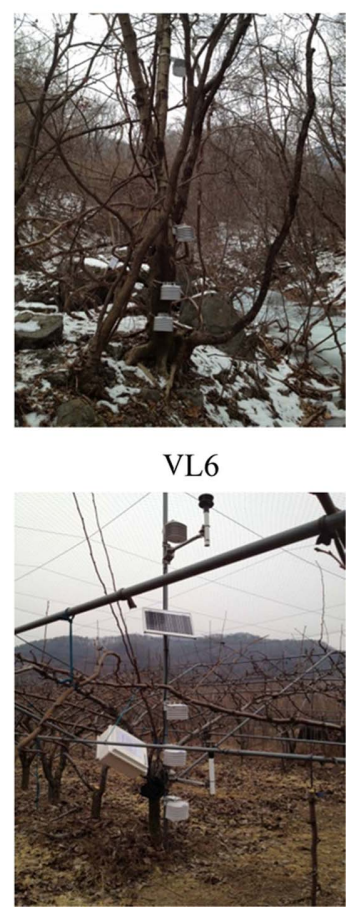

Fig. 3. Pictures of the Automatic Weather Stations in the observational sites along the valley.

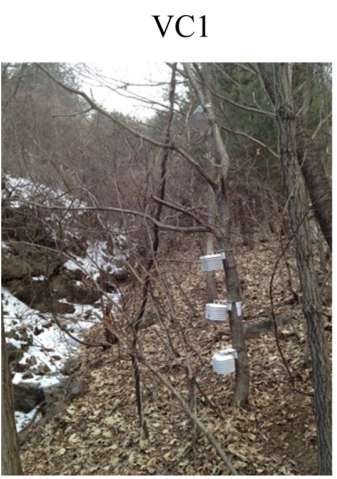

$\mathrm{VC} 4$

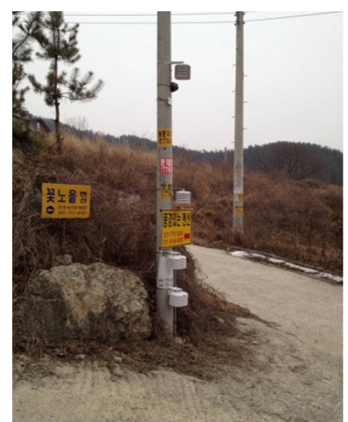

$\mathrm{VC} 2$

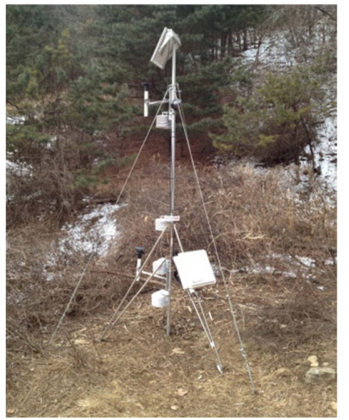

$\mathrm{VC5}$

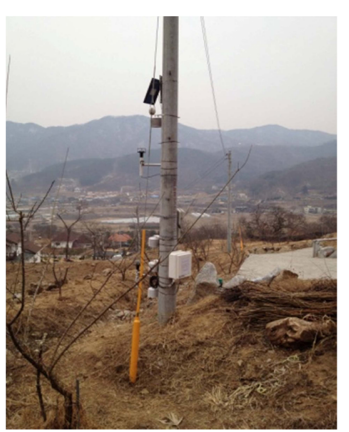

$\mathrm{VC} 3$

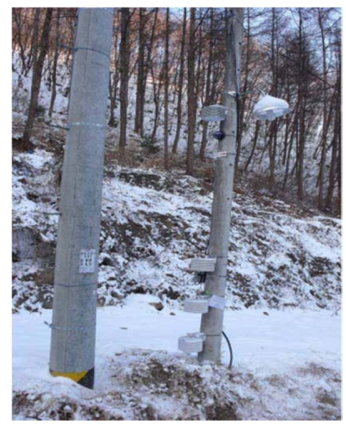

VC6

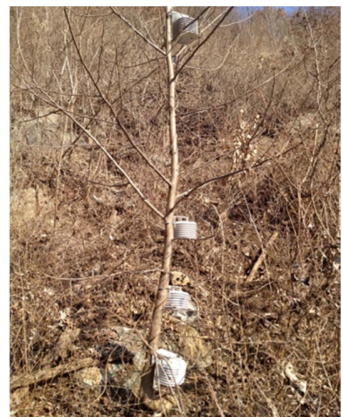

Fig. 4. Pictures of the Automatic Weather Stations in the observational sites across the valley. 
경우 2005년부터 2009년까지 5년간의 전국 78 개 농 업용 AWS 관측지점의 자료에서 극값을 조사하여 문 턱값을 정하였으나, 기상청 RQMOD에서 이용하는 물 리한계값과 크게 차이가 나지 않아서 기상청 $\mathrm{RQMOD}$ 의 물리한계값을 그대로 이용하였다. 그 외 나머지 관측 요소들은 기상청 $\mathrm{AWS}$ 의 관측치와 농업 용 $\mathrm{AWS}$ 의 관측치가 근본적으로 차이가 날 이유가 없으므로, 기상청 RQMOD에서 이용하는 물리한계값 과 센서의 측정한계를 이용하여 물리한계값을 결정하 였다(국립기상연구소, 2011, 2012).

연구기간 동안의 전기간 평균기온, 기온감률의 계산 에 있어서는 각 지점에서 지표의 영항을 가장 적게 받는 $3.5 \mathrm{~m}$ 높이의 온도자료를 사용하여 비교하였다. 그리고 일별 종관기상 상태는 기상청 산하 양평 정규 관측소에서 수집한 운량자료를 사용하였다. 또한 용문 산의 산악지역 기후 특성을 알아보기 위해서 기상청의 용문산 AWS자료와 양평관측소의 자료를 이용하여 비 교하였다.

\section{III. 결과 및 고찰}

\section{1. 용문산 지점의 봄철 기온 특징}

2012년 봄철(3 5월) 용문산과 양평에 설치된 기상청 $\mathrm{AWS}$ 관측자료에 의하면 일 평균기온은 $10.7,11.9^{\circ} \mathrm{C}$ 로 용문산 지역의 온도가 더 낮게 나타났다. 용문산 지점의 장기간 봄철 평균온도(2002-2012년)인 $10.4^{\circ} \mathrm{C}$ 와 거의 차이가 없었다. 일 최고 기온은 양평에서 $29.4^{\circ} \mathrm{C}$ 로 가장 높게 나타났고, 일 최저 기온은 용문산 에서 $-7.3^{\circ} \mathrm{C}$ 로 나타났다. 봄철 총 강수량은 용문산에 서 $262 \mathrm{~mm}$, 양평에서는 $228.5 \mathrm{~mm}$ 로 용문산에서 약 1.2 배정도 강수량이 많게 나타났다. 이로부터 용문산 지점은 양평에 비해서 온도가 낮고 강수량이 높은 특

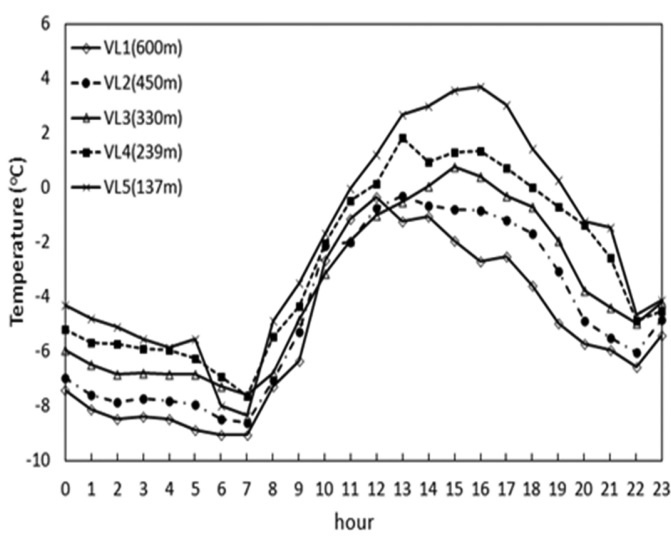

(a)

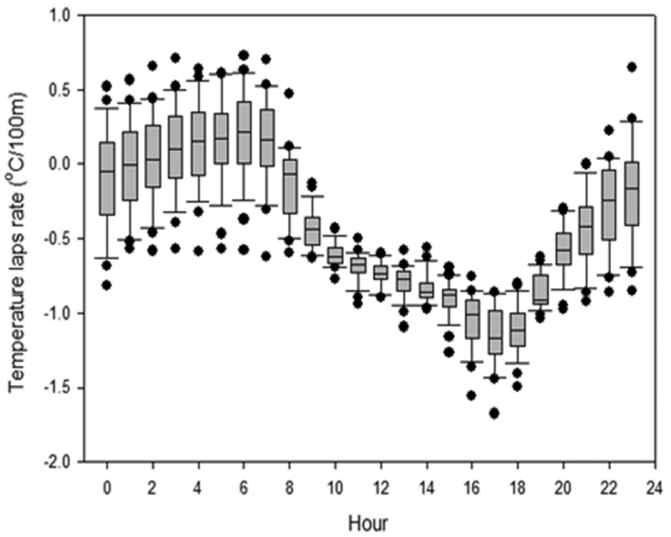

(b)

Fig. 5. (a) The diurnal variations of observed temperature, (b) box whiskers plot of temperature lapse rate between VL1 and VL5 $\left({ }^{\circ} \mathrm{C} / 100 \mathrm{~m}\right)$.

성을 가지고 있다는 것을 알 수 있다.

전 기간 동안의 시간평균 기온변화 곡선을 살펴보면 (Fig. 5(a)), 야간에는 산정상부분(VL1)과 저지대(VL5) 모두 기온이 서서히 낮아져서 유사한 기온변화폭을 보 이나, 주간에는 저지대(VL5)의 기온상승 정도가 산정

Table 2. Simple statistics of Mt. Youngmun and Yangpyung Automatic Weather Station (AWS) observation sites data operated by Korea Meteorological Administration (KMA)

\begin{tabular}{clccccc}
\hline \hline & & $\begin{array}{c}\text { Temperature } \\
\left({ }^{\circ} \mathrm{C}\right)\end{array}$ & $\begin{array}{c}\text { Precipitation } \\
(\mathrm{mm})\end{array}$ & $\begin{array}{c}\text { Rainy days } \\
(\text { days })\end{array}$ & $\begin{array}{c}\text { Wind direction } \\
(\text { degree })\end{array}$ & $\begin{array}{c}\text { wind speed } \\
(\mathrm{m} / \mathrm{s})\end{array}$ \\
\hline \multirow{3}{*}{$\begin{array}{c}\text { Yongmunsan } \\
\text { AWS }\end{array}$} & mean & 10.7 & 8.8 & 25 & 224.6 & 1.2 \\
& min & -7.3 & 0.5 & & 1.0 & 0.1 \\
\hline \multirow{3}{*}{ max } & 27.8 & 60.0 & & 359.9 & 4.4 \\
AWpyung & mean & 11.9 & 8.7 & 23 & 203.2 & 1.8 \\
& min & -6.7 & 0.5 & & 0.1 & 0.1 \\
& max & 29.4 & 54.0 & & 359.9 & 7.7 \\
\hline
\end{tabular}


상부(VL1) 기온변화폭에 비하여 훨씬 더 크게 나타남 을 알 수 있었다. 저지대의 경우 일출 정오 사이에 빠른 기온상승현상이 나타났다. 6시부터 15시까지 산 정상부분에서 시간에 따른 기온 상승률은 $0.89^{\circ} \mathrm{C} / 1$ 시 간 이지만 저지대에서의 기온상승률은 $1.45^{\circ} \mathrm{C} / 1$ 시간으 로 1.63 배 이상 높게 나타났다. 그 결과, 15 시의 저 지대와 산 정상부분의 기온 차는 오전 6 시의 기온 차 에 비해서 5.32배 이상 증가했다. 주간의 산 정상부분 의 경우에는 직접 자유대기와의 혼합효과가 탁월하지 만 계곡 내의 공기는 종관 기상현상의 직접적인 영향 을 덜 받아 일 최고기온이 나타나는 시간이 지연된다 (Richner and Phillips, 1984, Barr et al., 1989, Chung et al., 2009). 산 정상부분에서는 일 최고기온이 12시 경에 나타나지만 저지대에서는 16 시경에 나타났다. 또 한, 저지대의 기온은 서서히 하강하기 때문에 산정상 부와 저지대 지역의 기온 차가 가장 큰 시각도 1617시 경으로 더 늦게 나타났다.

산정상부의 VLl $(600 \mathrm{~m})$ 지점과 계곡 내 저지대

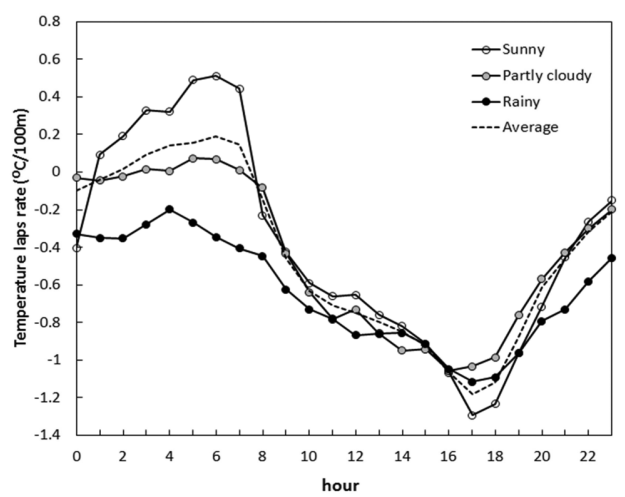

(a)
VL5 $(137 \mathrm{~m})$ 지점의 봄철 일 평균기온을 비교하면, 산정상의 일 평균온도는 $8.38^{\circ} \mathrm{C}$, 계곡 내 저지대의 일 평균온도는 $10.41^{\circ} \mathrm{C}$ 로 해발고도에 따른 봄철 평균 기온감률은 $-0.44^{\circ} \mathrm{C} / 100 \mathrm{~m}$ 로 나타났다. 전체기간 중 VL1과 VL5의 시간별 기온감률의 변화폭을 살펴보면 (Fig. 5(b)) 전반적으로 주간보다는 야간에 계절 내 기 온감률 변동성이 높게 나타남을 알 수 있었다. 가령 시간별 변동성과 관련하여 상하위 사분위 값과 평균으 로부터 10 퍼센타일 값의 변화를 살펴보면, 주간보다는 야간에 그 차이가 약 2 배 이상 크게 나타났다. 이 변 동성 시계열에서 하루 중 기온감률 변동성의 최대값은 아침 7-8시에 관찰되며, 가장 작은 변동성은 15 시에 나타났다. 아침 7-8시의 기온감률의 표준편차 $(0.24)$ 는 최저 변동성을 나타내는 15 시 기온감률 표준편차 (0.13)의 약 2 배 이상에 달한다. 이러한 결과들은 용 문산 지역의 기온감률 변동이 새벽에 가장 크게 나타 남을 잘 보여준다.

용문산 지역의 봄철 일평균, 일 최대, 일 최저 기온

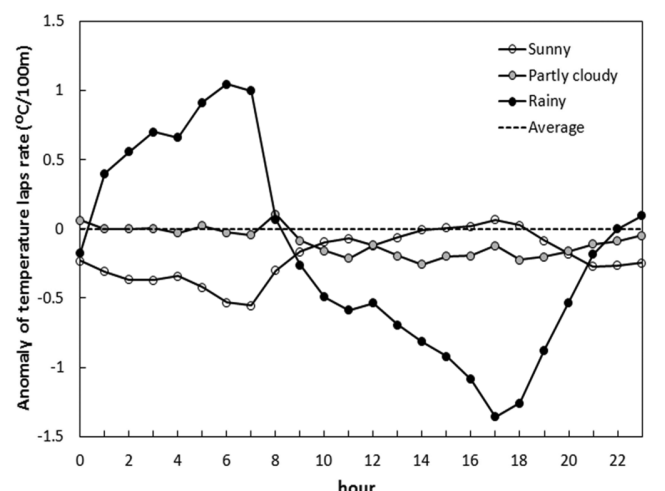

(b)

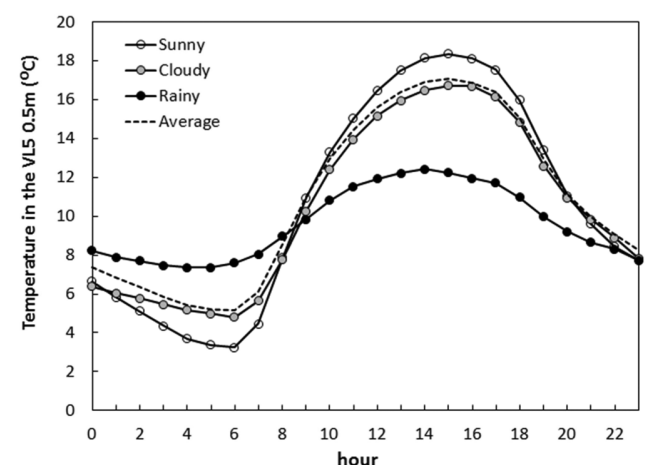

(c)

Fig. 6. Diurnal variations of (a) average, (b) anomaly of temperature laps rate and (c) surface air temperature in the bottom (VL5-0.5m) by weather conditions. 
Table 3. Springtime temperature laps rate $(\mathrm{C} / 100 \mathrm{~m})$ by weather conditions

\begin{tabular}{lcccc}
\hline \hline & Mean cloud & Minimum laps rate & Mean laps rate & Maximum laps rate \\
\hline Sunny (mean cloud 4) & 2.12 & 0.06 & -0.48 & -1.07 \\
Partly cloud (mean cloud $>$ 5, No rain) & 5.72 & -0.22 & -0.40 & -0.81 \\
Rainy & 5.88 & -0.16 & -0.41 & -0.92 \\
\hline
\end{tabular}

감률은 종관기상의 상태에 따라 그 값과 나타나는 시 각이 상이하게 나타났다. 용문산의 일별 종관기상 상 태는 양평 정규관측소에서 수집한 자료를 사용하여 2012년 봄철을 크게 맑은 날, 흐린 날, 강수일로 구분 하였다. 운량을 기준으로 운량이 4이하인 날을 맑은 날, 운량이 5 이상이고 강수가 없는 날을 흐린 날로 간주하였다.

봄철 일평균 기온감률은 맑은 날에 $-0.48^{\circ} \mathrm{C} / 100 \mathrm{~m}$ 로 봄철 평균 기온감률보다 크고, 강수일에는 $-0.41^{\circ} \mathrm{C} /$ $100 \mathrm{~m}$ 로 평균 기온 감률 값 $\left(-0.44^{\circ} \mathrm{C} / 100 \mathrm{~m}\right)$ 과 유사하 게 나타났다. 흐린 날에는 기온감률이 $-0.40^{\circ} \mathrm{C} / 100 \mathrm{~m}$ 로 상대적으로 작게 나타났다. 즉, 용문산의 봄철 일 평균 기온감률은 맑은 날, 강수일, 흐린 날 순으로 높 음을 알 수 있었다. 그리고 일 최고 기온감률도 역시 같은 순서로 나타났다. 일 최저 감률은 강수일, 흐린 날, 맑은 날 순으로 나타났는데 맑은 날의 일 최저값 은 심지어 기온감률이 양의 값을 보이기도 했다. 즉, 맑은 날에는 해발고도가 상승하면 오히려 기온이 증가 하는 기온역전현상이 발생하는 것이다. 대체로 대부분 의 종관일기 상태에서는 일 최고 기온감률은 오후 4 5시에, 일 최저 기온감률은 오전 5 7시에 관찰되는
데 용문산의 경우도 이와 같은 결과가 관측되었다.

종관 일기별로 하루 시간 진행에 따른 기온감률의 변화를 살펴보면(Fig. 6a), 강수일에는 기온감률의 변 동범위가 $-0.2 \sim-1.1^{\circ} \mathrm{C} / 100 \mathrm{~m}$ 로 주 · 야간 사이에 차이 가 뚜렷하지 않았다. 강수일에는 구름의 영향으로 계 곡 내 저지대의 복사 냉각현상이 약화되고, 주간에는 태양복사에너지의 유입을 감소시켜 지표복사가 잘 이 루어지지 않기 때문이다(Oke, 1988; Barry, 2008). 맑은 날에는 주. 야간 기온감률의 하루 중 변화범위가 $-1.3 \sim 0.5^{\circ} \mathrm{C} / 100 \mathrm{~m}$ 로 그 변동 폭이 상대적으로 커졌다. 맑은 날 야간에는 지표복사냉각이 활발하게 나타나 지 면의 인접대기의 온도가 뚜렷하게 하강하는 반면, 주 간에는 상대적으로 더 많은 태양복사에너지가 유입되 어 지표상의 공기가 쉽게 가열되기 때문이다(Geiger et al., 2009). 맑은 날 새벽(0 7시)의 기온감률은 평 균과 비교하여 $0.4^{\circ} \mathrm{C} / 100 \mathrm{~m}$ 이상 작게 나타났다. 맑은 날 야간에는 사면을 따라 냉각된 무거운 공기가 흘러 내려 저지대로 모아져 냉기호(cold pool)를 형성한다. 연수리 계곡 내에서도 맑은 날 새벽에는 저지대(VL5) 의 기온이 봄철 전체 새벽 평균기온보다 $-1.9 \sim-0.7^{\circ} \mathrm{C}$ 낮아지고, 기온감률도 양의 값을 보인다(Fig. 6c). 대

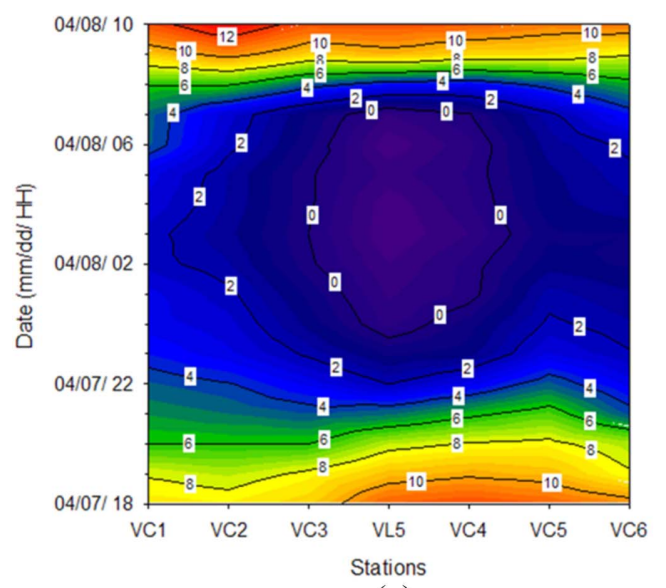

(a)

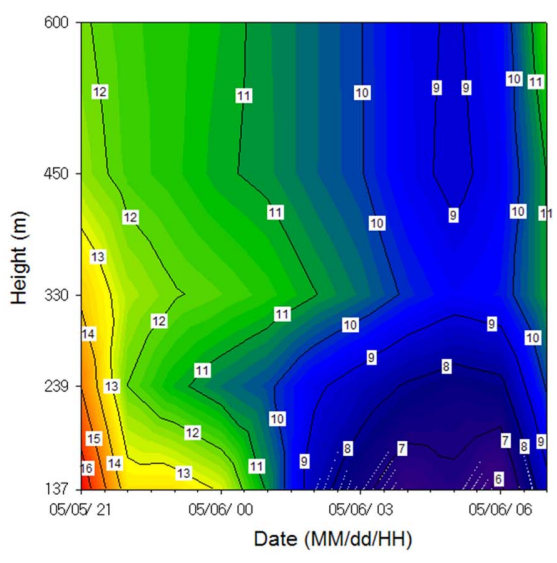

(b)

Fig. 7. Observed temperature of (a) cold pool and (b) thermal belt. 
조적으로 호우일 새벽에는 구름에 의한 장파복사의 간 섭에 의해 복사냉각이 줄어들어 계곡 내 저지대에서는 평균 야간기온보다 $0.8 \sim 2.2^{\circ} \mathrm{C}$ 높은 온기호(warm air pool)을 형성한다(Chickering, 1884; Dunbar, 1966; Yoshino, 1984, Zangl, 2005).

\section{2. 용문산 계곡에서의 냉기호와 온난대 형성}

Fig. 7은 용문산 계곡에서 나타나는 냉기호와 온난 대 현상을 나타낸 그래프이다. (a)는 4월 7일 일몰 후부터 4월 8 일 일출 전까지 냉기호의 형성과정을 잘
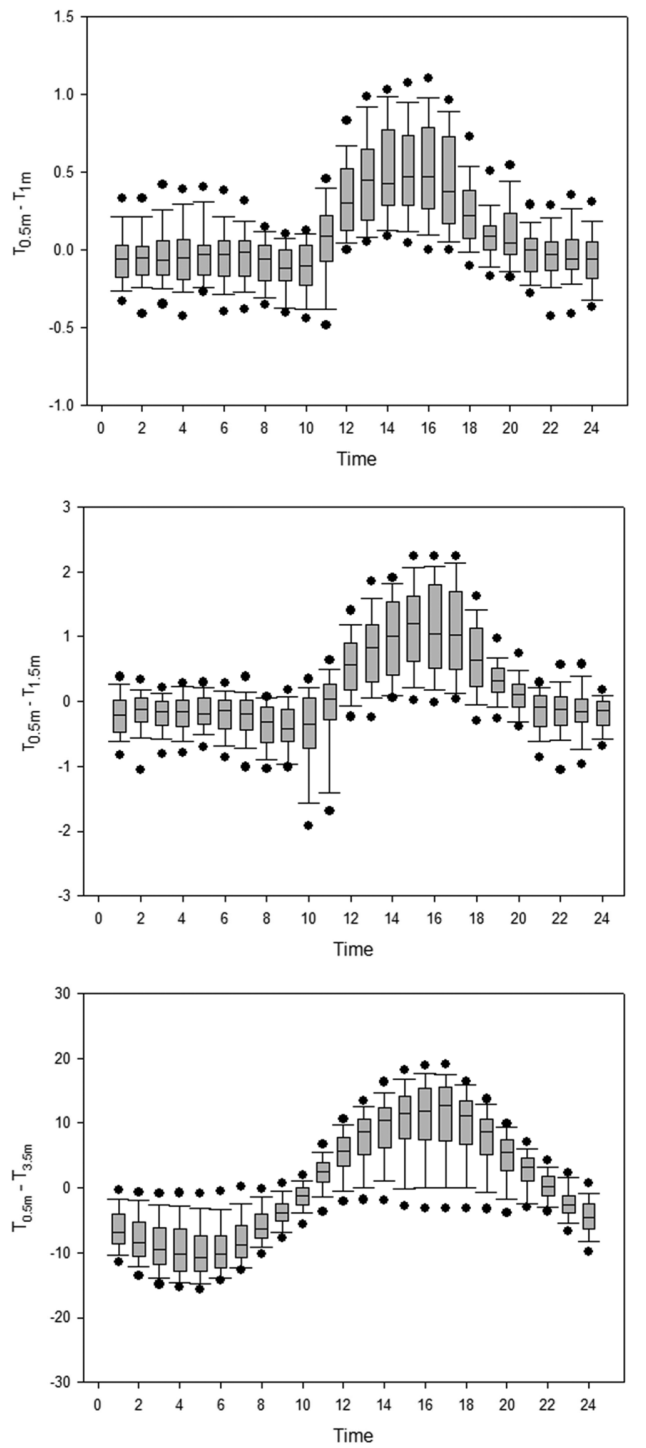

(a) VC6
나타내고 있는 그림이다. 18시 이후 계곡의 정상 부분 부터 온도가 감소하기 시작하여 22시경 계곡 하부의 온도가 급격히 감소하여 03시에는 온도가 최저에 이르 며 냉기호가 형성되었다. 이 냉기호는 일출 이후에도 유지되다가 8시 이후에 완전히 소멸되었다. 이러한 냉 기호의 형성은 활발한 지표복사 냉각작용도 뿐 아니라 계곡을 따라 냉각된 공기의 무게로 인해 흘러내리는 냉기의 흐름으로 인해 일어난 것이다. (b)는 5 월 5 일 21시부터 5월 6일 7시까지 용문산의 횡방향으로 설치 된 온난대 관측지점에서 관측된 시간에 따른 고도별
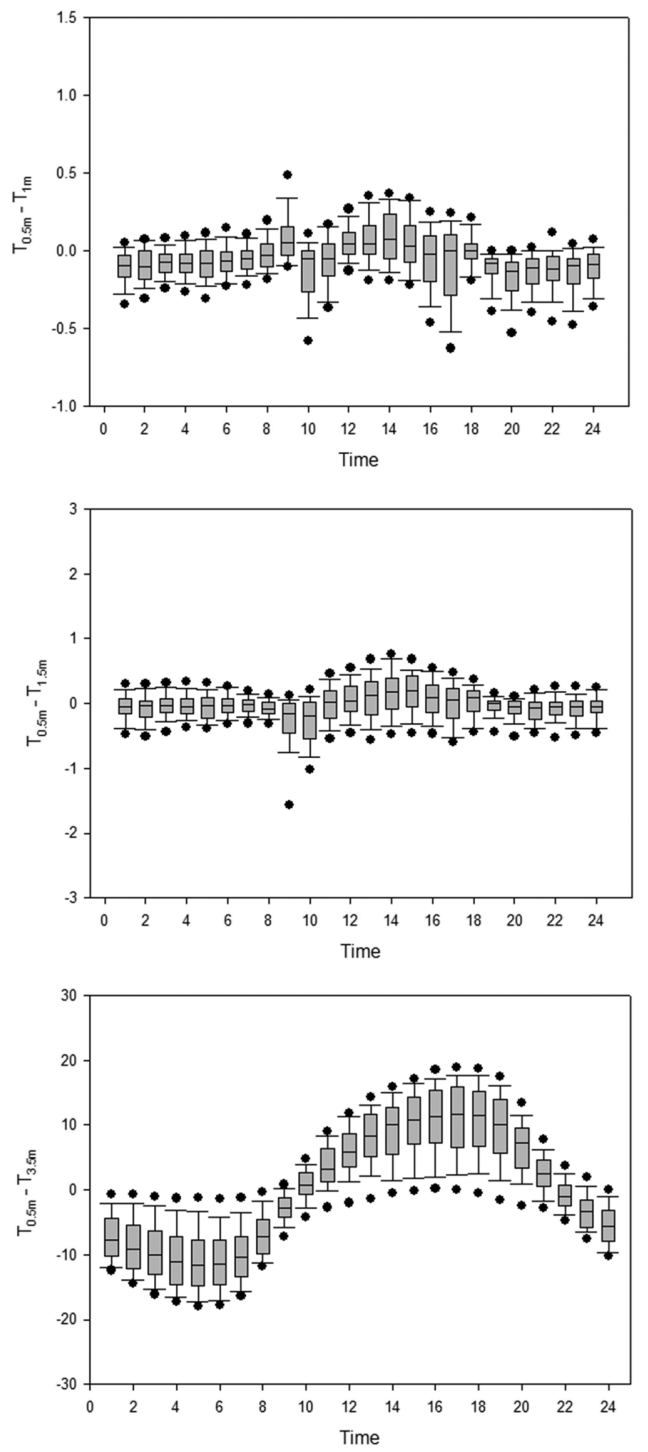

(b) VL5

Fig. 8. Mean differences of air temperature between $0.5 \mathrm{~m}$ and $1 \mathrm{~m}, 1.5 \mathrm{~m}$, or $3.5 \mathrm{~m}$ at (a) VC6 and (b) VL5 stations. 
온도변화 그래프이다. 온난대가 형성된 높이는 계곡 저지대(VL5: $137 \mathrm{~m}$ )로부터 약 $100 \sim 300 \mathrm{~m}$ 사이이며 제일 고도가 낮은 부분과의 온도차는 약 $4^{\circ} \mathrm{C}$ 였다. 고 도가 낮은 지역 $(239 \mathrm{~m}$ 이하)은 21 시부터 1 시까지 온 도가 $16^{\circ} \mathrm{C}$ 에서 $10^{\circ} \mathrm{C}$ 까지 무려 $6^{\circ} \mathrm{C}$ 가 감소하는 반면 고도가 높은 지역은 $13^{\circ} \mathrm{C}$ 에서 $11^{\circ} \mathrm{C}$ 까지 약 $2^{\circ} \mathrm{C}$ 의 온도변화가 있었다. 따라서 23시 이후에 산중턱에 온 난대가 형성되며 5 시간정도 유지되다가 5 시 이후에는 온도가 고도가 낮은 쪽의 온도와 유사해지며 온난대가 소멸되었다. 이는 대기 중 지면과 접촉한 부분의 공기 가 장파복사에 의해 빠르게 냉각되고, 상공의 공기는 느리게 냉각되어 온난대가 형성되는 기존의 연구결과 들과 일치한다(Chickering, 1884; Dunbar, 1966, Kim et al., 1967, Kwon et al., 1990, Lee, 2009).

\section{3. 관측 높이별 특징}

연수리 계곡 내 각 관측 높이 별로 온도 변화를
알아보기 위해 각 지점별로 $0.5,1,1.5,3.5 \mathrm{~m}$ 높이 의 온도를 측정하였다. 각 지점의 온도를 최하층 $(0.5 \mathrm{~m})$ 의 온도와 비교하여 높이별 온도 특성에 대해 알아보았다(Fig. 8). 연수리 계곡의 냉기형성을 알아보 기 위한 관측망 중 가장 고도가 높은 VC6 $(242 \mathrm{~m})$ 지점과 계곡 최저지점에 위치한 VL5 (137m)지점의 온도를 비교하여 보았다. 각 지점의 높이에 따른 온도 차이를 비교해보면 $0.5 \mathrm{~m}$ 에서 $1.5 \mathrm{~m}$ 의 고도가 낮은 $\mathrm{VL} 5$ 지점이 $\mathrm{VC} 6$ 지점에 비해 일변화가 작고 상하층간 의 차이도 적게 나타났다. 이는 VL5지점에서는 지면 으로부터 $1.5 \mathrm{~m}$ 지점까지는 혼합이 잘되어 지면의 영 향을 많이 받는 층이 존재하기 때문이다. 반면에 $\mathrm{VC} 6$ 지점은 밤시간에는 상하간의 온도변화가 적으나 12 시 이후에 $0.5 \mathrm{~m}$ 의 온도가 급격히 높아지는 것으로 보아 주간에 태양복사에 의해 지표면의 가열과 야간의 복사냉각이 VL5지점보다 활발히 일어나고 있음을 알 수 있다. 일반적으로 계곡에서는 낮에는 골바람이 불

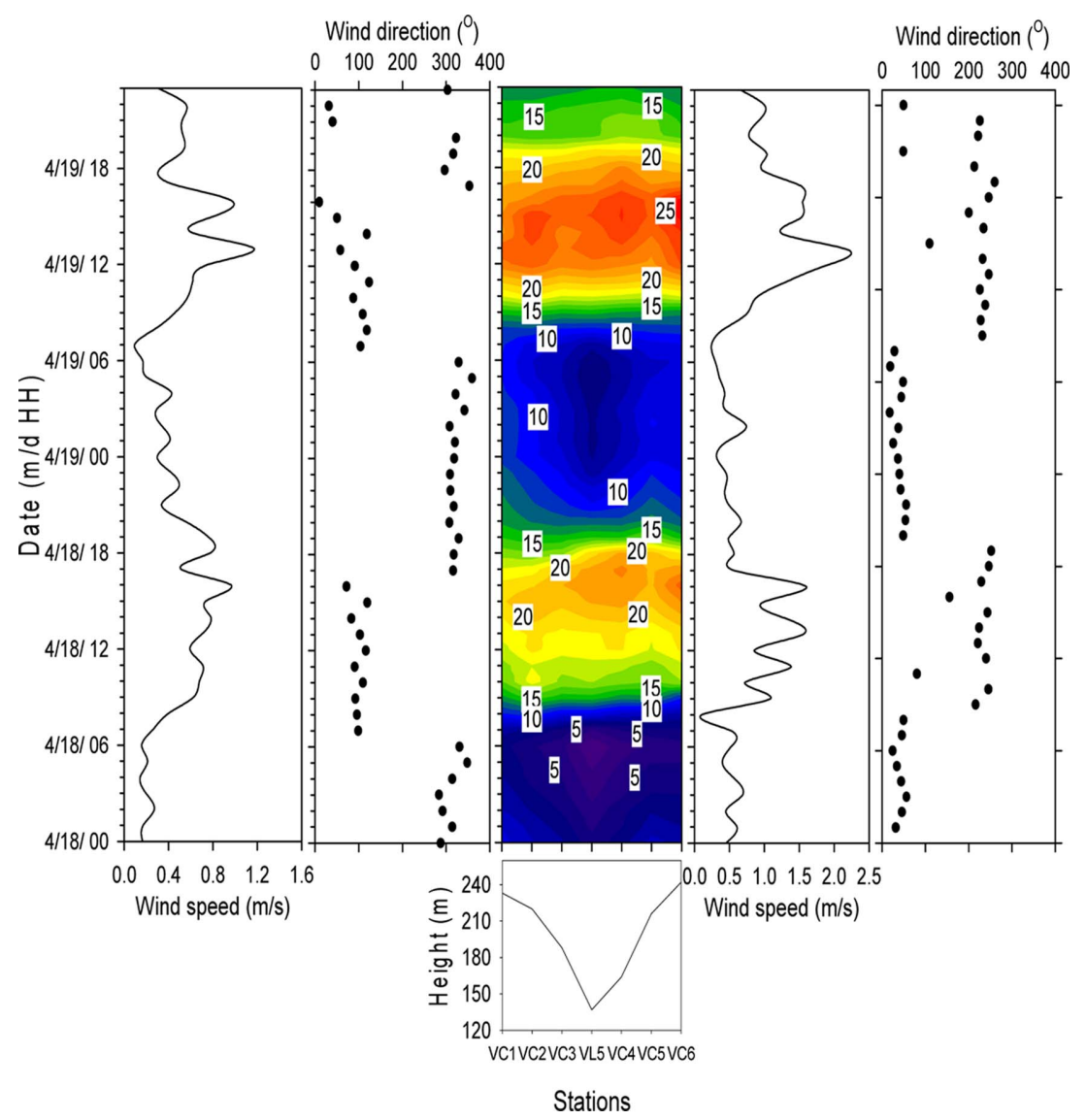

Fig. 9. Distribution of wind speed, wind direction and temperature across the valley. 
고 밤에는 산바람이 부는 것으로 알려져 있다. 낮에는 경사면 및 골짜기가 일사에 의해서 가열되고 거기에 접한 공기가 가벼워져서 상승하게 때문에 골바람이 불 고, 밤에는 복사냉각에 의해 무거워진 공기가 낮은 곳 으로 향하기 때문에 산바람이 분다(Fig. 9). 이러한 현상은 주로 맑고 바람이 약한 날 뚜렷하게 발생하며 이를 확인하기 위해 종관풍이 약한 날 중에서 맑은 날과 비가 오는 날을 정하여 비교하여 보았다. $\mathrm{VC} 2$ 의 $3.5 \mathrm{~m}$ 높이에서의 풍향과 풍속을 사례별로 비교하 였다. 맑은 날은 비가 온 날에 비해 일사량이 많아 낮과 밤의 풍향변화가 뚜렷하게 나타나고 풍속 또한 강하게 나타나는 것을 확인 할 수 있었다(Fig. 10).

Fig. 11은 전체 관측기간 동안의 $\mathrm{VC} 2, \mathrm{VC} 5$ 의 높 이별 $(1,3.5 \mathrm{~m})$ 풍향 및 풍속의 시간평균을 종관 풍속 에 따라 구분하여 나타낸 그래프이다. 양평관측소의 $10 \mathrm{~m}$ 바람관측 자료를 이용하여 풍속이 $2.5 \mathrm{~m} / \mathrm{s}$ 이상인 날과 이하인 날로 구분하여 두 지점에서 종관풍의 영 향을 알아보고자 하였다. 두 지점 모두 높은 곳 (3.5m)에서 풍속이 세고, $\mathrm{VC} 5$ 지점이 $\mathrm{VC} 2$ 지점에 비해 풍속이 강하게 나타났다. 종관풍이 약할 때(Fig. 11)
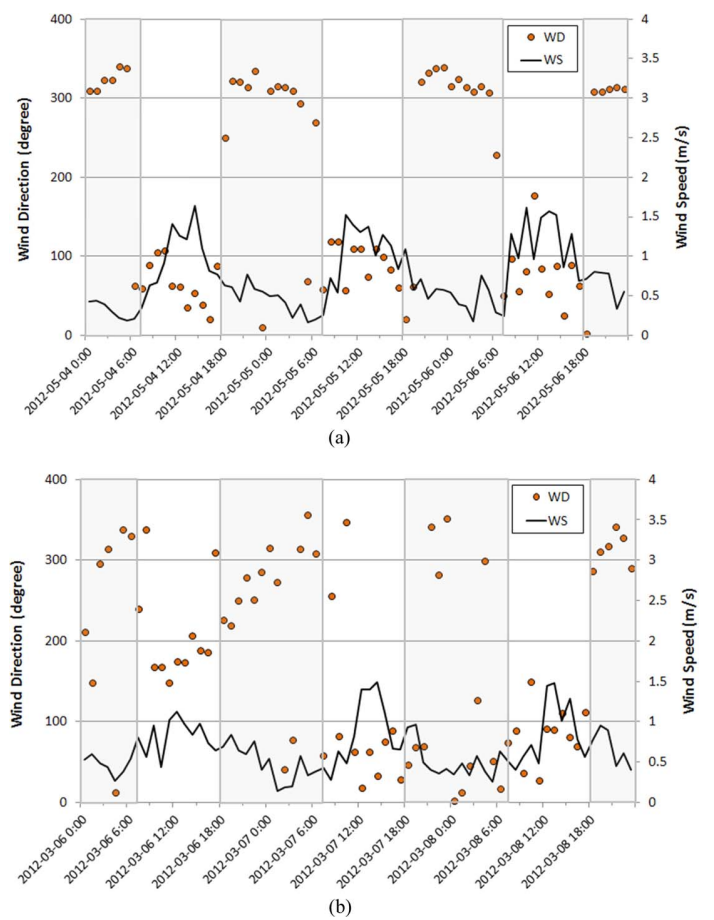

Fig. 10. Distribution of wind speed and direction at VC2 on the (a) clear day and (b) rainy day.
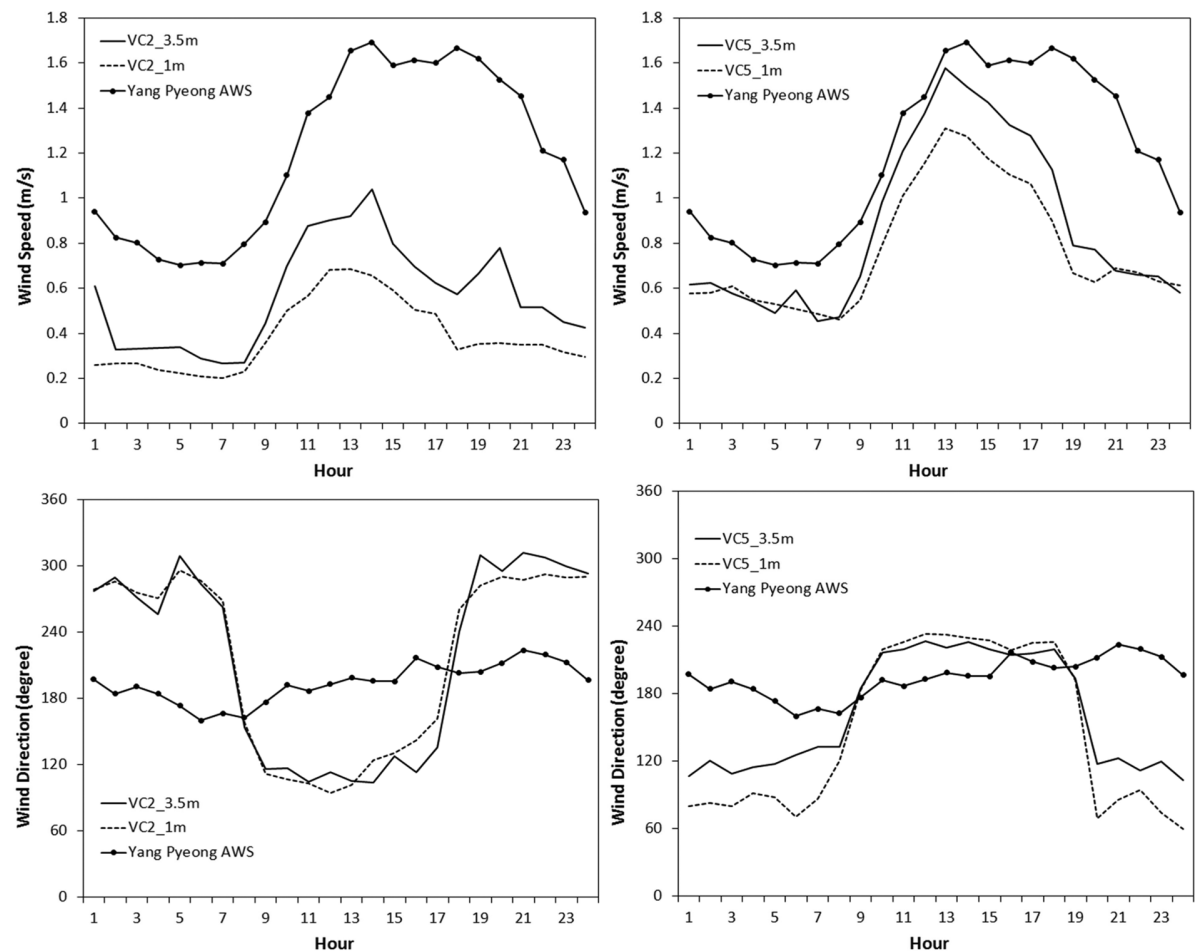

Fig. 11. Wind speed and direction observed at VC2 and VC5 stations at $3.5 \mathrm{~m}$ and $1 \mathrm{~m}$ heights during weak synoptic conditions. 

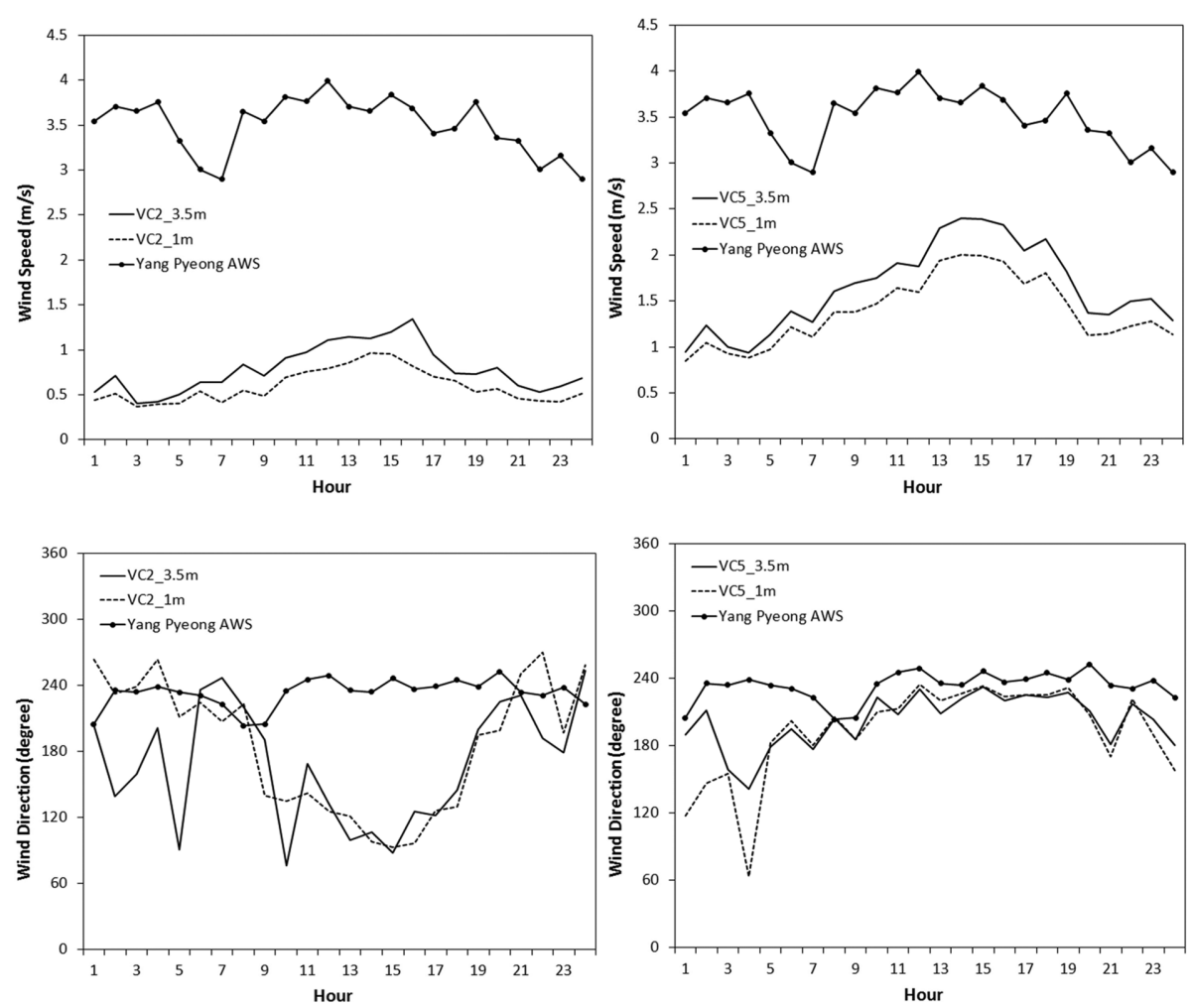

Fig. 12. Wind speed and direction observed at VC2 and VC5 stations at $1 \mathrm{~m}$ and $3.5 \mathrm{~m}$ heights during strong synoptic conditions.

$\mathrm{VC} 2$ 지점은 주야간에 풍향의 변화가 뚜렷하게 나타나 고 풍속이 종관풍에 비해 낮게 나타난 반면, $\mathrm{VC5}$ 지 점은 풍향의 변화가 적게 나타나고 풍속은 종관풍과 비슷한 경향을 나타내었다. 이를 보아 VC5지점은 $\mathrm{VC} 2$ 지점에 비해 종관풍의 영향을 많이 받고 있음을 알 수 있었다. 또한 종관풍이 강한 사례에서도(Fig. 12) $\mathrm{VC} 5$ 지점은 주야간의 풍향의 차이가 없고 종관풍 과 유사한 풍향을 나타내고 있었다. $\mathrm{VC} 2$ 는 종관풍속 이 강할 때 주야간의 풍향의 차이가 줄어들고 야간에 는 종관풍과 유사한 풍향을 나타내기도 하였다. $\mathrm{VC2}$ $(220 \mathrm{~m})$ 와 VC5 $(216 \mathrm{~m})$ 는 두 지점 모두 야산의 중턱 에 위치하고 있으나, $\mathrm{VC} 2$ 지점은 무덤가로 주변에 식 생으로 둘러싸인 반면 VC5지점은 열린 공간에 위치 하여 종관풍의 영향을 상대적으로 많이 받고 있었다. 따 라서 $\mathrm{VC} 5$ 지점은 $\mathrm{VC} 2$ 지점에 비해 국지적인 산곡풍이 뚜렷하게 발생하지 못했다.

\section{적 요}

본 연구는 경기도 양평군 용문면 연수리 계곡에서 관측을 통하여 봄철 용문산 계곡의 온도 및 바람의 시공간적인 특성을 밝히고자 하였다. 2012년 3월부터 5 월까지 기온 및 2, 3차원 바람을 관측하고 자료를 수집하였다. 연수리 계곡의 집중관측 자료를 분석한 결과, 용문산의 전기간 평균 기온감률은 $-0.44^{\circ} \mathrm{C} /$ $100 \mathrm{~m}$ 이며 맑은 날 $\left(-0.48^{\circ} \mathrm{C} / 100 \mathrm{~m}\right)$, 강수일 $\left(-0.41^{\circ} \mathrm{C} /\right.$ $100 \mathrm{~m}$, 흐린 날 $\left(-0.40^{\circ} \mathrm{C} / 100 \mathrm{~m}\right)$ 순으로 기온감률이 낮 아지는 것을 알 수 있었다. 기온상승률은 산 정상부분 $\left(0.89^{\circ} \mathrm{C} / 1\right.$ 시간)에서 탁월한 대기와의 혼합효과에 의한 영향으로 계곡하부 $\left(1.45^{\circ} \mathrm{C} / 1\right.$ 시간 $)$ 보다 낮게 나타난다. 맑은 날 야간에는 산사면을 따라 냉각된 공기가 흘러 내리는 현상이 온도와 바람장을 통해 확인하였다. 또 한 계곡 저지대로부터 $100-300 \mathrm{~m}$ 사이에서 온난대 형성 도 확인 할 수 있었다. 산정상과 계곡하부에서 측정한 고도별 온도분포의 관측결과 계곡하부에서는 지면으로 부터 $1.5 \mathrm{~m}$ 까지 지면의 영향을 받는 냉기층이 존재함을 알 수 있었다. 관측 높이별 바람분포를 관측한 결과 풍 속은 높은 곳 $(3.5 \mathrm{~m})$ 에서 강하며 비슷한 고도에 위치한 
지점이어도 종관풍의 영향을 많이 받는 지점은 국지적 인 바람의 패턴이 뚜렷하게 나타나지 않고 있었다.

\section{감사의 글}

본 연구는 국립기상연구소의 주요 연구과제 “응용기 상기술개발연구” 과제 및 기상청 차세대도시농림융합스 마트기상서비스개발(WISE) 사업(153-3100-3133-302350)의 지원으로 수행되었습니다.

\section{REFERENCES}

Barr, S., and M. M. Orgill, 1989: Influence of external meteorology on nocturnal valley drainage winds, Journal of Applied Meteorology 28, 497.517.

Barry, R. G., 2008: Mountain Weather and Climate (3rdeds.), Cambridge University Press, New York.

Chickering, J. W. Jr., 1884: Thermal belts, American Meteorological Journal 1, 213-218.

Chung, U., H. C. Seo, J. I. Yun, S. J. Jeon, K. H. Moon, H. H. Seo, and Y. S. Kwon, 2009: Extrapolation of daily maximum temperature in a mountainous terrain, Asia Pacific Journal of Atmospheric Sciences 45(4), 473-482.

Chung, U., H. H. Seo, K. H. Hwang, B. S. Hwang, J. Choi, J. T. Lee, and J. I. Yun, 2006: Minimum temperature mapping over complex terrain by estimating cold air accumulation potential, Agricultural and Forest Meteorology 137, 15-24.

Choi, G. Y., B. R. Lee, S. K. Kang, and J. Tenhunen, 2010: Variations of Summertime Temperature Lapse Rate within a Mountainous Basin in the Republic of Korea A case study of Punch Bowl, Yanggu in 2009. Journal of the Korean Association of Regional Geographers 16(4), 339-355.

Dunbar, G. S., 1966: Thermal belts in North Carolina, Geographical Review 56(4), 516-526.

Geiger, R., R. H. Aron, and P. Todhunter, 2009: The Climate Near the Ground (7theds.), Rowman \& Littlefield Publishers, Inc., New York, 52.

Hong, S. J., and H. S. Ryu, 1997: The topography and landscape of the YangPyung. The second report on the national natural environment, 1-6.

Heo, B. H., J. A. Lee, Y. O. Choo, J. H. Kim, N. C. Park, J. Y. Cho, S. J. Oh, M. S. Nho, and Y. J. Lee, 2005: Realtime Quality control system for Meteorological Observation Data (RQMOD). Journal of the Korean Meteorological Society, 390-391.

Kim, B. G., and Y. H. Park, 1967: The origin of the socalled Punch Bowl. Journal of the Geological Society of Korea 3, 61-66.
Kwon, Y. S., H. H. Lee, U. Han, W. H. Kim, D. J. Kim, D. I. Kim, and S. J. Youm, 1990: Terrain analysis of Haean basin in terms of earth science. Journal of Korean Earth Science Society 11(3), 236-241.

Lee, J. Y., 2009: Importance of hydrogeological and hydrologic studies for Haean basin in Yanggu. Journal of the Geological Society of Korea 45(4), 405-414.

Lee, M. H., B. W. Lee, Y. H. Kim, J. H. Lee, Y. H. Son, J. S. Chae, C. I. Jang, J. B. Lee, T. G. Oh, and S. H. Bae, 2010: The current situation of agricultural and fishery sectors and their measures for the global climate change. The Korean Academy of Science and Technology Research Report, 7.

National Institute of Meteorological Research, 2011: Advanced Research on Industrial Meteorology (IV), 19-23.

National Institute of Meteorological Research, 2012: Advanced Research on Bio- and Industrial Meteorology (I), 8-24.

Oke, T. R., 1988: Boundary layer climates (2ndeds.), Routledge, New York.

Richner, H., and P. D. Phillips, 1984: A comparison of temperature from mountaintops and the free atmosphere - their diurnal variation and mean difference, Monthly Weather Review 112, 1328-1140.

Seo, H. C., S. J. Jeon, and J. I. Yun, 2008: Azimuthal distribution of daily maximum temperatures observed at sideslopes of a grass-covered inactive parasitic volcano ("Ohreum") in Jeju Island. The Korean Journal of Agricultural and Forest Meteorology 10(1), 25-31.

Song, H. Y., 2000: Characteristics of temperature distribution in mountain valley in winter. Han-Wol Academy, 121.

Yun, J. I., 2009: A simple method using a topography correction coefficient for estimating daily distribution of solar irradiance in complex terrain. The Korean Jornal of Agricultural and Forest Meteorology 11(1), 13-18.

Yun, J. I., D. S. Lee, J. Y. Choi, S. I. Cho, E. W. Park, and H. Hwang, 1999: Elevation-corrected spatial interpolation for near-real time generation of meteorological surface from point observation. AgroInformatics Journal 1(1), 28-33.

Yun, J. I., J. Y. Choi, and J. H. Ahn, 2001: The effect of climate data applying temperature lapse rate on prediction of potential forest distribution, The Korean Journal of Agricultural and Forest Meteorology 3(2), 96-104.

Yun, J. I., J. Y. Choi, Y. G. Yun, and U. Chung, 2000: A spatial interpolation model for daily minimum temperature over mountain regions, The Korean Journal of Agricultural and Forest Meteorology 2, 175-182.

Yoshino, M. M., 1984: Thermal belt and cold air drainage on the mountain slope and cold air lake in the basin at quiet, clear night, GeoJournal 8(3), 235-250.

Zangl, G., 2005: Dynamical aspects of wintertime cold-air pools in an Alpine valley system. Mon. Wea. Rev. 133 : 27212740, http://dx.doi.org/10.1175/MWR2996.1. 